\title{
CIRCULAR ECONOMY OPPORTUNITIES FOR ECONOMIC EFFICIENCY IMPROVEMENT IN WOOD-BASED PANEL INDUSTRY
}

\author{
Nikolay Neykov ${ }^{1}$, Petar Antov ${ }^{2}$, Viktor Savov ${ }^{3}$ \\ ${ }^{1}$ Faculty of Business Management, University of Forestry, 10 Kliment Ohridski Blvd., Sofia, Bulgaria \\ ${ }^{2,}{ }^{3}$ Faculty of Forest Industry, University of Forestry, 10 Kliment Ohridski Blvd., Sofia, Bulgaria \\ E-mails: ${ }^{1} n n e y k o v @ l t u . b g$ (corresponding author); 2 p.antov@ltu.bg; ${ }^{3}$ victor_savov@ltu.bg
}

Received 09 March 2020; accepted 06 May 2020

\begin{abstract}
The enhanced technological possibilities to utilise wood waste and residues in the production of wood-based panels can help towards the transition to a circular, low-carbon bioeconomy. The cascading use of wood resources, defined as "the efficient utilisation of resources by using residues and recycled materials for material use to extend total biomass availability within a given system" is one of the leading principles for achieving this goal. The wood-based panel industry is characterised by significant amounts of waste and residues that present a great volume potential for cascading. The aim of the present study is to define the basic guidelines for cascading use of wood waste from the production of wood-based panels and analyse the economic impact in terms of economic efficiency in line with the circular and bioeconomy principles. Time series analysis of wood waste and raw material flows in the Republic of Bulgaria, economic assessment of the current utilisation of wood waste in the wood-based panel industry along with comparative analysis of the potential utilization methods have been presented. The existing technical and market barriers to the cascading use of wood have also been discussed.
\end{abstract}

Keywords: circular economy, wood-based panels, economic efficiency, cascading use, sustainability.

JEL Classification: Q23, Q32, D61, L53.

\section{Introduction}

The concept of a circular economy (CE) argues that products do not quickly become waste, but are reused to extract their maximum value before safely and productively returning to the biosphere (Ellen-MacArthur-Foundation, 2013). Circular Economy moves away from waste as the end-state of consumption and focuses on business practices where waste is recovered and products are reused (Gregson et al., 2015), i.e. turns goods into resources (Valavanidis, 2018).

Circular economy lies on close-loops (Jawahir \& Bradley, 2016) and is based on: Reduction in usage of natural resources; Increase in the usage of renewable, recyclable resources; Reduction in the carbon emissions; Reduction in the material wastes and minimization of losses; Maintenance of economic value of goods, materials and components (European Environment Agency, 2016). All these elements, or principles can be implemented throughout so called business models (Ionescu et al., 2017). The principles embedded in the circular economy are now emphasized in process and product design. This has introduced several visionary concepts i.e. the bioeconomy, the bio-based society and the green economy that are now redirecting the strategic planning of many industrial companies (McCormick \& Kautto, 2013).

The scarcity of primary wood resources and the growing environmental consciousness are the main driving forces for shifting the scientific interest towards the sustainable use of wood resources, and optimisation of wood resource efficiency.

The existing studies on the effects of circular economy on woodworking companies are scarce in the context of enterprise economic efficiency. Sirking and ten Hooten (1994) investigated the implications and applications of the concept and the principles of cascading as a tool for the appropriate design of products and production processes and as a possible foundation for a sustainable resource management policy. Geldermann et al. (2016) adopted interdisciplinary perspective allowing a comprehensive overview of current research on resource efficiency of renewable materials, but in general, and not in the context of woodworking or wood-based panel industry. Risse et al. (2017) discovered that cascading of wood leads to less resource consumption compared to the use of primary wood, indicated by higher resource efficiency ( $46 \%$ vs. $21 \%$ ) at life cycle level. The research was focused on the economies of resources throughout the product lifecycle and primary wood products 
like rounwood. Many of the studies in the field, like Knauff (2015) and Sikkema et al. (2017) are focused on the resource effectiveness and the sectoral or spatial effect of CE. Most of the research on $\mathrm{CE}$ was conducted to examine resource scarcity and environmental impact (Mair \& Stern, 2017).

At present there are no studies based on the comparative economic efficiency prior to taking the managerial decision how to utilize wood residuals from wood-based panel production in the conditions of resource constraint. The complex effect of different types of benefits and opportunity costs in the wood-based panel industry should be assessed in order to justify the involvement of circular economy principles. The current study is focused on investigating the role of each $\mathrm{CE}$ principle, implemented in company development in terms of direct and opportunity costs. The study complements the costs analysis made by Daian and Ozarska (2009), Kharazipour and Kües (2007), and Largay (2009).

The Bulgarian company which has been investigated in the study presents the great opportunity for assessment of the economic efficiency of CE principles in wood-based panel industry. It combines the wood residuals with wood composites production. Bulgarian woodworking companies still do not express a great willingness to adopt and implement CE practice which determines the role of the current study as a strong evidence of their usefulness. The results obtained would support the implementation of CE not only in the studied company and the other Bulgarian woodworking enterprises, but will also provide a critical point of view prior to the implementation of CE principles in the wood-based panel industry in general. The period investigated comprises data from the last four years: 2016-2019.

\section{The CE opportunitiof CE measures es for waste utilization and circles formation}

The wood panel industry stands out when waste is regarded (Carvalho et al., 2019, p. 105). Wood waste consists of wood pieces and particles generated from the industrial or small-scale processing of wood, construction and demolition activities and broken-down wood products (Owoyemi et al., 2016). Wood panel industry produces wide variety of waste: outlet water including wood fibres (Thoemen, 2010); wood composite waste (Kharazipour \& Kües, 2007); solid wood in a variety of forms and preservatives (Owoyemi et al., 2016), including veneers from the plywood production
(Sumardi et al., 2018); emissions of toxic gases (Carvalho et al., 2019).

Wood panel industry along with many economic branches has been the subject of extensive studies in the context of transformation from $3 R$ (reduce, reuse and recycle) (Hai, 2020) to 6R (the Thes + revaluation, redistribution, and relations) (Stahel, 2019, p. 15). This means that circular economy measures should be spread even in fields, considered as inappropriate till now. To date, material utilisation of wood waste has been limited to particleboard production (Faraca et al., 2019), more than to MDF (Daian \& Ozarska, 2009) or other panels. Concerns appear in the usage of contaminated wood (Suttie, 2004) and utilise it mostly for thermal use (Jones \& Puignou, 1998; Suttie, 2004). However, new ways for advanced utilization have been proposed (Mantanis et al., 2002). Summarizing the ways of utilization of the wood waste (Daian \& Ozarska, 2009) and so called CE practices (Carvalho Araújo et al., 2019) in production of plywood, hardboards and particleboards:

- Recycle - reuse of residuals like fibres (Antov \& Savov, 2019; Antov et al., 2019) or recycling whole panels (Mantanis et al., 2004; Roffael et al., 2002, 2010, 2016; from after customer waste after stages of cutting or defective production appearance.

- Cascading use - defined as "the efficient utilisation of resources by using residues and recycled materials for material use to extend total biomass availability within a given system" (Vis et al., 2016) is probably the most common practice and takes place in the EU countries in a variety of forms and contexts. Wood chips or other waste like veneer shorts (Lyubov \& Popov, 2017) can be used for pallet production, fibreboards, packages, etc.

- Incineration - the use of waste is wide common and requires good eco-friendly combustion processes to reduce the toxic emissions of adhesives used.

- Composting - a simple decomposition process of organic matter under aerobic and controlled conditions (Wróblewska et al., 2008). Composting some of the waste like resifues from fibreboards production or non-treated particles can be even profitable if any fees can be escaped by it. However, the process results in significant amounts of leftover materials, such as composts and sludge (Odlare et al., 2011). 
Most of the described above practices or CE tools present so called inner-circles (EllenMacArthur-Foundation, 2013) except recycling from the final consumers. They provide intraenterprise close-loops (circles) or inter-enterprise circles. Inter-enterprise circles in wood panel industry can be described also as inter-industry if they use waste from other sectors, e.g. agriculture. This CE opportunity would not narrow the raw materials assortment, but would reduce the amount of round wood used. Many studied on wood panel production are dedicated to this topic (Antov et al., 2017; Flandez et al., 2012; Mendes et al., 2012; Mihailova et al., 2019; Mishra \& Naik, 2005; Prithivirajan et al., 2015). The most important here are the technological issues connected with the utilization of agricultural waste and residues.

\section{Waste utilization and its costs}

In the current study the utilization of wood waste and supplementary resources like outlet water is considered in the context of possibilities to reduce costs. With the rising prices and reduced supply of raw wood from forests, recycling of wood waste is nevertheless recognised an economically attractive alternative - in addition to that the material reuse (Kharazipour \& Kües, 2007). This statement reveals utilization like resourse induced under conditions of scarce wood raw materials.

In fact, determining the right costs and their assignment to the source of waste reveals the efficiency of the particular circle if benefits are clear. Daian and Ozarska (2009) proposed the following types of costs: the costs of wasted raw material (waste multiplied to the price of the raw materials it comes from); disposal costs; associated costs overheads (Largay, 2005) for administrating the waste. Hidden costs can also appear (Kies et al., 2016) like different type of inefficiencies.

\section{Materials and methods}

In the current study economic efficiency is assumed to be the technical efficiency (Coelli et al., 2005) of raw materials in the production of woodbased panels, particularly hardboards and plywood. The costs described above are included into efficiency ratio (Shiba, 1997) in single output and multiple input. The analysis of efficiency and particularly the technical efficiency gives the major highlights of reducing the deficiencies. One of the most recommendable approaches for that is the Data Envelopment Analysis (DEA). It was introduced by Charnes et al. (1978) for the assessment of relative efficiency of similar economic units (DMU) that use particular inputs to produce outputs. DEA provides a measure of efficiency of each DMU allowing, in particular, to separate efficient from non-efficient DMU and to indicate for each non-efficient DMU its 'efficient peers' (Bouyssou, 1999). As DMUs in the current study are accepted the Circular Economy Opportunities (CEOP).

The existence of constant returns to scale (CRS) of waste utilization gives the compound effect of waste utilization inputs over the outputs benefits. Making the assumption on that could bias the results of pure economic efficiency. Variable return to scale (VRS) model seems to be appropriate for the purpose of the current study, in order to take into account effect of scaling. The model is used in the following envelopment form (dual model):

Step 1 - estimation of efficiency

$\min \theta$,

Subject to: $\sum_{i=1}^{n} \lambda_{i} x_{i j}-\theta x_{0} \leq 0$

$\sum_{i=1}^{n} \lambda_{i} y_{i j}-y_{0} \geq 0$.

Step -2 estimation of slacks:

$$
\max \sum_{i=1}^{n} s^{-}+\sum_{r=1}^{s} s^{+},
$$

Subject to:

$$
\begin{aligned}
& \sum_{i=1}^{n} \lambda_{i} x_{i j}-\theta x_{0}=-s^{-}, \\
& \sum_{i=1}^{n} \lambda_{i} y_{i j}-y_{0}=s^{+},
\end{aligned}
$$

where: $\lambda j$ are individual coefficients of $j$-th Circular Economy Opportunity (CEOP); $\theta$ is the socalled efficiency scores and $\theta^{*}$ is the optimal efficiency, delivered by the first step. Notations $s+$ and $\mathrm{s}^{-}$are slacks that measure shortage of benefits from the opportunity (notated as $y_{0}$ for the particular CEOP being estimated) or surplus of resources $\left(x_{i j}\right.$ $i$-th type of resource of $j$-th CEOP).

For the purpose of the efficiency estimation the CEOP are divided into the four alternatives, which present the possible outcomes i.e. benefits. They are: cascading peeler block into HDF; Cascading peeler blocks into packages; cascading HDF into packages; recycling HDF; thermal use of all waste.

In the model, applied in this study, the costs and benefits for each CEOP are as follows: 
- Input one: Direct costs. Costs of generating the waste.

- Input two: Opportunity costs. Costs for omitting the most profitable opportunity of others, utilizing the waste in the current, in the context technological constraints.

- Output: Benefits. Here are included all the economies or raw materials and costs for heating and steam production by alternative energy sources, and revenues from selling the packages.

The model above is supplemented with one of net-benefits ratio $\left(N B R_{j}\right.$ of $j$-th opportunity) in order to translate the results from DEA to most understandable way for the practitioners. The model is:

$$
N B R_{j}=\left(y_{j}-\sum x_{i j}\right) / Q,
$$

where: $y_{j}-\sum x_{i j}$ is the net-benefit of $C E O P_{j}, Q-$ annual quantity of the wood based panels produced, $\mathrm{m}^{3}$.

The approach, proposed in analytical form by Cooper et al. (2007). and successfully implemented in many papers like Zadmirzaei et al. (2016), has also been used in the present paper. It is called scale efficiency (SE) and is expressed by the following equation:

$$
S E=\Theta *_{C C R} / \Theta *_{B C C} .
$$

The subject of the present study is a plywood and HDF production plant in Bulgaria. It is the only one of its business in the country and offers great opportunities for applying the circular economy approaches. The plant utilizes the waste of wood residuals in two CEOP:

- Cascading - plywood production waste is used to produce fibres for production of HDF and packages, such as euro pallets; production waste from $\mathrm{HDF}$ is used to produce crate bottoms.

- Thermal (energy) utilization. Residues from plywood production that content wood treatment are not suitable to cascading in HDF.

All data about the direct costs were provided by the enterprise, but all opportunity costs are estimated in the study. Data from the enterprise were averaged for the last four years. Specific DEA software: DEA Frontier was used to perform the calculations.

\section{Results for efficiency}

The enterprise produces about $33000 \mathrm{~m}^{3} \mathrm{HDF}$ and $35000 \mathrm{~m}^{3}$ plywood per year and the average prices are $260 € / \mathrm{m}^{3}$ and $440 € / \mathrm{m}^{3}$, respectively. Direct costs, opportunity costs and the benefit (output) are presented in Table 1.

Table 1. CEOP parametters - inputs and outouts in the eterprise, in $€$ per year

\begin{tabular}{|l|c|c|c|}
\hline \multicolumn{1}{|c|}{ CEOP } & $\begin{array}{c}\text { Direct } \\
\text { costs }\end{array}$ & $\begin{array}{c}\text { Opportunity } \\
\text { costs }\end{array}$ & Benefits \\
\hline $\begin{array}{l}\text { Cascading the } \\
\text { peeler blocks } \\
\text { into HDF }\end{array}$ & 55725,064 & 132938,51 & 201298,7 \\
\hline $\begin{array}{l}\text { Cascading the } \\
\text { peeler blocks } \\
\text { into packages }\end{array}$ & 52214,255 & 201298,7 & 29057,278 \\
\hline $\begin{array}{l}\text { Thermal use of } \\
\text { waste after } \\
\text { cutting }\end{array}$ & 569104,36 & 230355,98 & 9898558,1 \\
\hline $\begin{array}{l}\text { Cascading the } \\
\text { HDF residuals } \\
\text { into packages }\end{array}$ & 132938,51 & 45071,071 & 613078,82 \\
\hline $\begin{array}{l}\text { Cascading the } \\
\text { all waste into } \\
\text { HDF }\end{array}$ & 286050,11 & 10540694 & 372967,58 \\
\hline
\end{tabular}

All the values in the table were calculated from data provided by the enterprise, e.g. prices or raw materials, costs of generating the waste and types of alternatives for heat and steam production. The last ones are produced in the power plant included in the facilities of the enterprise.

The so-called efficiency scores are illustrated on Figure 1 (Korkmaz, 2011; Sporcic et al., 2009), calculated by DEA, by individually estimating the efficiency including one or another input or both. The input and output are calculated in value.

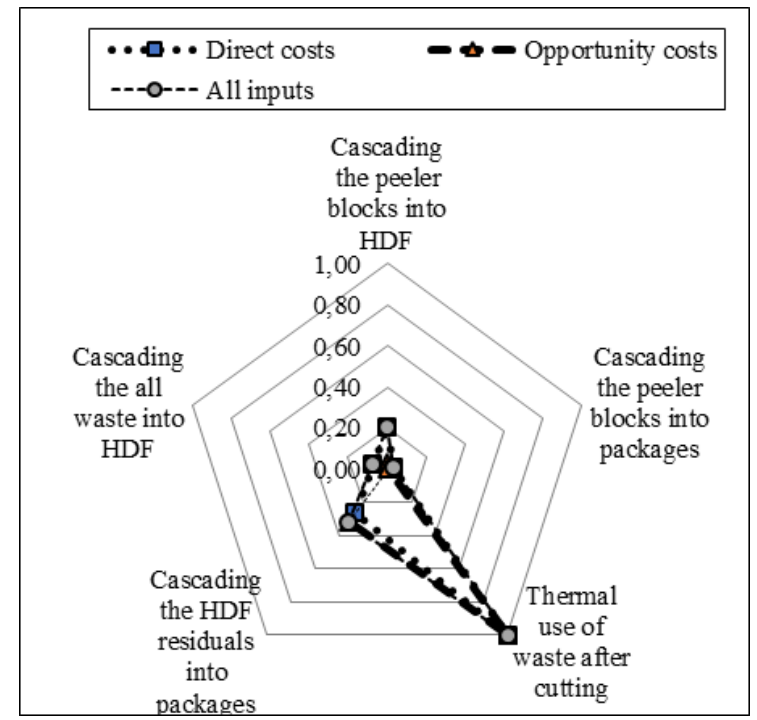

Figure 1. Efficiency scores in different CEOP and CCR model 
The CCR model gives the information about scale influence on the each CEOP. From the figure presented it is clear, that the most efficient CE opportunity is thermal utilization of the wood waste. Its has $100 \%$ efficiency in the meaning of DEA, i.e. its not necessary to reduce waste implemented there and relocate it to another alternative. Other scores are:

- Cascading the peeler blocks into HDF 0.2 with input direct costs and both, and 0.03 for opportunity costs like input.

- Cascading the peeler blocks into packages 0.0033 for all the alternatives.

- Cascading the HDF residuals into packages -0.26 for direct costs and 0.31 for others.

- Cascading all waste into HDF - 0.00082 for opportunity costs and 0.074 .

The results reveal that the opportunity costs for all CEOP except "Thermal use" are so great, that the economic effect is achieved within about $0.082-3 \%$ of direct and opportunity costs. Cascading peeler blocks into packages is not worth. It would be better to include them into other Circular Economy Opportunities, e.g. HDF production. Thermal use is the most economically efficient due to high energy costs in Bulgaria and expensive alternative of wood waste like fuel - liquid fuels. The result prove that high costs for energy sources determine the most efficient alternative and restrict the variety of CEOP.

The BCC model with so called the pure technical efficiency (Kovalčík, 2011) provide results of $100 \%$ for all CEOP, except all waste into HDF $22 \%$. This means that scale matters. The results are shown in Table 2.

Table 2. SE for the investigated CEOP in different DEA estimations in respect of the inputs

\begin{tabular}{|l|c|c|c|}
\hline & $\begin{array}{c}\text { All } \\
\text { inputs }\end{array}$ & $\begin{array}{c}\text { Direct } \\
\text { costs }\end{array}$ & $\begin{array}{c}\text { Opportunity } \\
\text { costs }\end{array}$ \\
\hline $\begin{array}{l}\text { Cascading the } \\
\text { peeler blocks into } \\
\text { HDF }\end{array}$ & 0.21 & 0.21 & 0.04 \\
\hline $\begin{array}{l}\text { Cascading the } \\
\text { peeler blocks into } \\
\text { packages }\end{array}$ & 0.03 & 0.03 & 0.00 \\
\hline $\begin{array}{l}\text { Thermal use of } \\
\text { waste }\end{array}$ & 1.00 & 1.00 & 1.00 \\
\hline $\begin{array}{l}\text { Cascading the } \\
\text { HDF residuals } \\
\text { into packages }\end{array}$ & 0.32 & 0.27 & 0.32 \\
\hline $\begin{array}{l}\text { Cascading the all } \\
\text { waste into HDF }\end{array}$ & 0.33 & 0.33 & 0.19 \\
\hline
\end{tabular}

All results given in Table 1 show that the efficiency is lost by the scale, except the "Cascading all waste into HDF" SE is smaller than technical efficiency. According to interpretation of similar results by Diaz-Balteiro and Romero (2008) the reason for the last opportunity to be more scale efficient than technical is the quality of processes of cascading. It has to be improved. All other CEOP have to increase their scales in order to achieve better economies. This does not mean to increase the amount of the inputs, but to enlarge output to the efficient scale.

If the thermal utilization is fully efficient opportunity, until the energy sources are expensive, it is useful to compare others, excluding the thermal use. The results are presented on Figure 2.

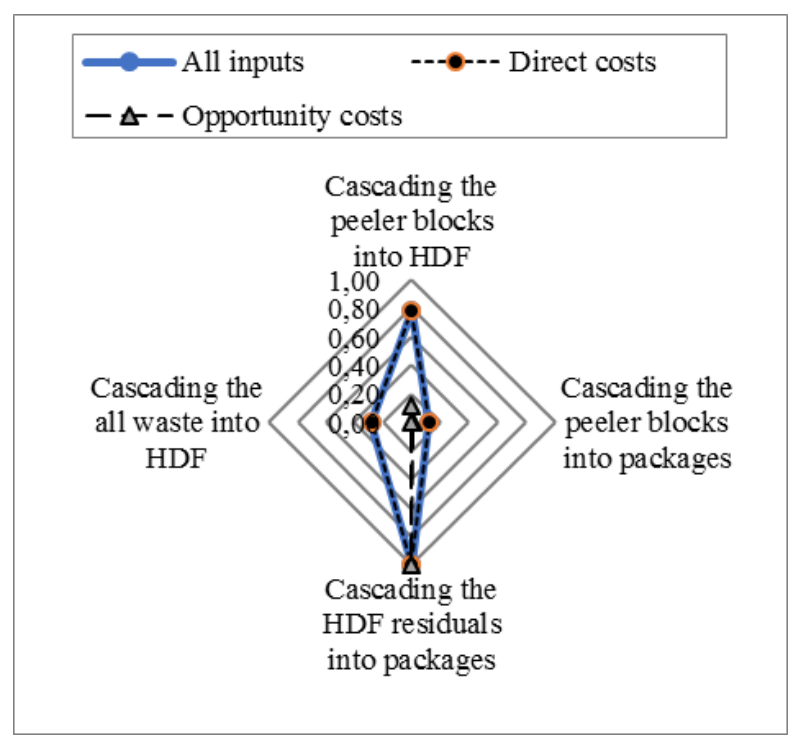

Figure 2. Efficiency scores in different CEOP and CCR model without thermal utilization

The figure presents that if the thermal utilization like a CEOP is accepted as "Ceteris Paribus", it is reasonable to make a comparison between other alternatives. Cascading peeler blocks into packages is not an efficient opportunity in both analyses - Figure 1 and Figure 2. It should be substituted with cascading into HDF. This is the best option (CEOP) with 0.58 average efficiency scores (averaging the all scores of cascading connected to the HDF). Cascading waste from HDF final production to packages is a profitable option if thermal utilization capacity is full. Cascading all waste into HDF is again with higher SE, than technical efficiency. It is clear that until the processes have not been improved the utilization of the waste from plywood for production of HDF, and future recycling the HDF residuals will not be efficient. 
Calculating the NBR, the results summarized the effect of improving the efficiency, which is suggested by DEA (Figure 3 ).

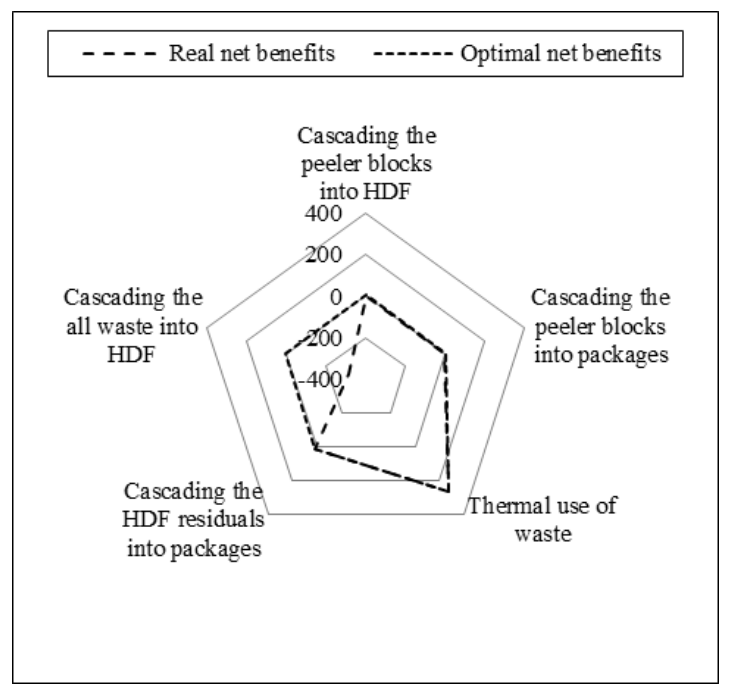

Figure 3. NBR by alternatives in $€ / \mathrm{m}^{3} \mathrm{HDF}$

The figure presents that the opportunity which requires serious influence by the enterprise management is cascading the waste into HDF. All described CEOP are real and optimal before and after DEA suggestions for inputs levels. This means that investments in processes of using the waste in HDF production would provide great leap for economic development of the enterprise. According to the other parameters given in the factory's accounting documents (annual costs for one employee are estimated to $7500 €$ ), the NBR can be transformed into labor costs, or reserves for future investments:

- The sum of net benefits from CEOP would cover the maintenance of 101 employees (if thermal CEOP is not taken into account), using the current way of utilization and 118 if they use the optimal way.

- Financial resources for investments in about 890 thousand $€$ per year.

All the benefits above are forecasted in the manner that they will appear if: the prices are improved; the production lines work on the levels close to $33000 \mathrm{~m}^{3} /$ year, and revenues from packages remain at least of the average levels from the recent years.

\section{Perspectives for future development of CEOP}

Future prospects are defined in this study by sectoral features, such as market-oriented, others driven by practices. Market-oriented perspectives can be summarized as the availability of resources in the recent years, prices for roundwood, finished production and energy. Practice - driven are the CEOP, which have been chosen by the majority of woodworking enterprises in Bulgaria and the tendencies in their intensity.

Figure 4 presents the growth rates of the main parameters, connected with the production of wood-based panels and the Circular Economy issues like wooden waste generated by the sector.

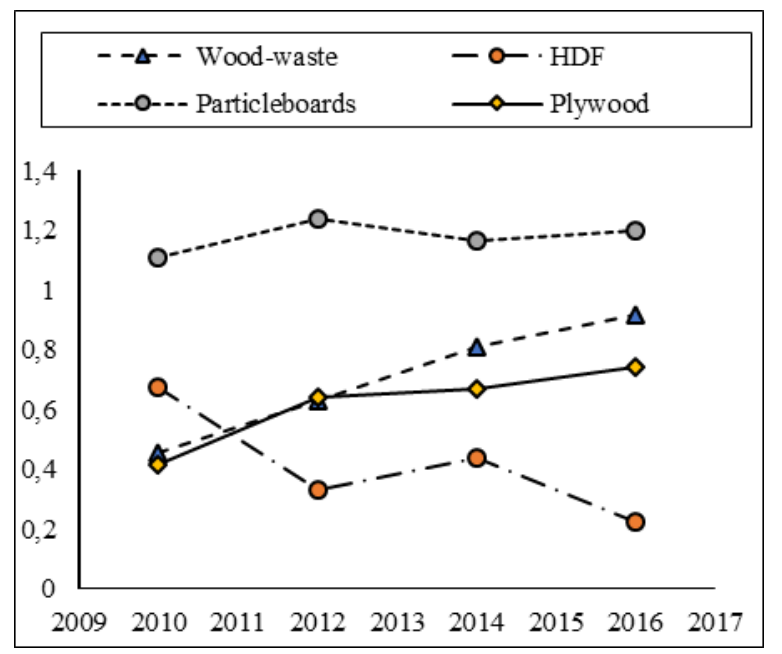

Figure 4. Growth rates of the main products in wood based panels production and wood waste generated, $2008=1$ (Forestry Production and Trade (2020) by Faostat and Sawnwood and panels (2020) by Eurostat)

As shown on the figure, until 2012 the production of plywood was the main generator of wood waste. CEOP like utilizing all the residues from plywood in the investigated enterprise into HDF becomes more and more emergent. Using the closed loops from the final customers like particular campaigns or permanent activity can be the alternative which should not be neglected. The information is supplemented by the data provided in the next graphic (Figure 5).

The Figure 5 shows that until 2016 the scarcity of raw materials was not the main issue, but the costs requirements. Highly increased imports put a pressure on producers' competitiveness. They have to maintain the average costs at the levels that allow selling price adjustments. This is not an easy task if the raw material prices are getting higher and competition becomes more aggressive. Data presented cover the period from 2008 to 2016, but afterward the problem of coniferous roundwood scarcity appeared, which additionally complicated the task of the management, along with the practice driven perspectives (Figure 6). 


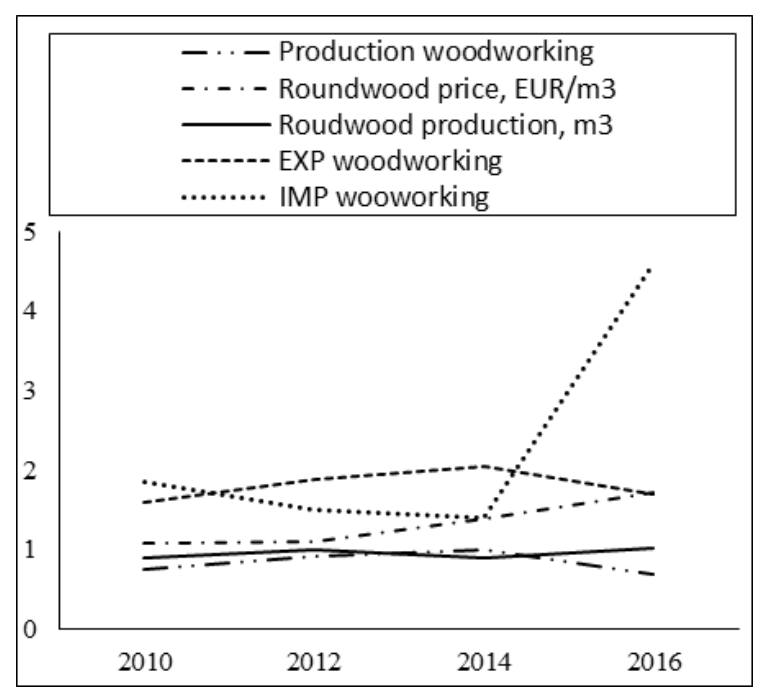

Figure 5. Growth rates of the main flows from and into the woodworking of Bulgaria, $2008=1$ (Sawnwood and panels (2020) and Roundwood removals by type of wood and assortment (2020) by Eurostat)

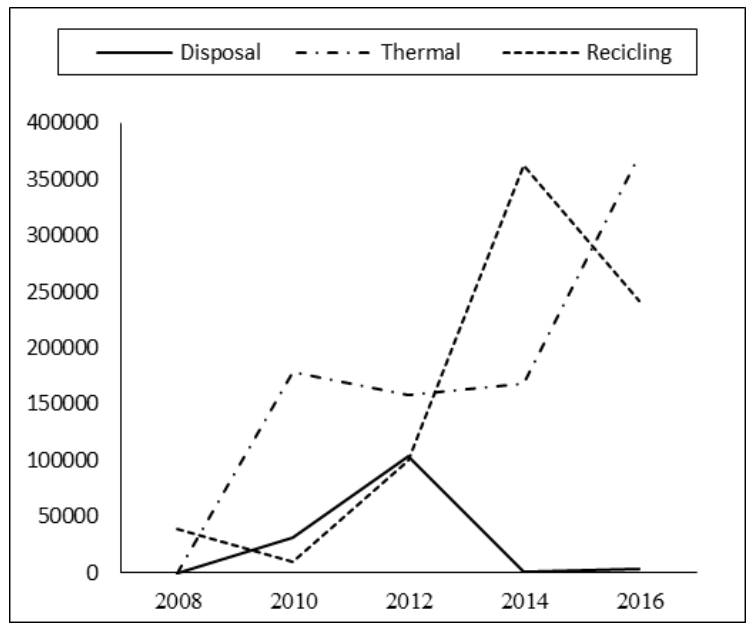

Figure 6. Growth rates of the wood waste utilization practices in Bulgaria, $2008=1$ (Forestry Production and Trade (2020) by Faostat)

The figure reveals the appeared market niche for supplying the wood waste for recycling. However, the increased usage of wood waste as fuel reveals the constant need of cheap energy in the country, which can be optimally achieved by incinerating wood. So the measures have to be simultaneously committed into two directions, all in the context of costs economies: cascading/recycling more waste and investments in energy efficient facilities.

\section{Conclusions}

The current study analysed the efficiency, derived by implementation of some Circular Economy Opportunities in the practice of wood-based panel industry. It was estimated that the practice of cascading use of wood can be very efficient if the market parameters are appropriate. The costs for specific resources like energy put the constraints in Circular Economy decisions. Despite the wide variety of opinions in the literature dedicated to the waste utilization, the current study for the first time reveals the effect of economic conditions rule over the intensity of the Circular Economy appearance. Unlike other research in the field, this study revealed that $\mathrm{CE}$ opportunities like cascading and recycling are strongly limited by the opportunity costs appeared after supplying expensive energy (steam, electricity, etc.). Taking into consideration the most expensive production factor or resource like "Ceteris Paribus", company management can focus on the different types of utilization or loops.

The models implemented here proved their ability to outline the current condition of the efficiency after implementing CEOP. In combination with the sectoral perspectives the management of the wood-based panel producing enterprises can develop and establish a strategy for cost efficiency improvement, based on the Circular Economy principles. The model used complements the cost and benefit assessment methods developed so far in the implementation of CE methods with the combination of direct and alternative costs, which have the function of guiding management decisionmaking. The study is limited in the B2B interaction in wood-panels production, but should be further extended to B2C interactions (like in Tukker, 2015) in context of HDF.

\section{Funding}

This work was supported by the project No. НИС5-1002/03.2019 'Exploitation Properties and Possibilities for Utilization of Eco-friendly Biocomposite Materials', implemented at the University of Forestry, Sofia, Bulgaria.

\section{Disclosure statement}

None of the authors have any competing financial, professional, or personal interests from other parties.

\section{References}

Antov, P., \& Savov, V. (2019). Possibilities for manufacturing eco-friendly medium density fibreboards from recycled fibres - a review. In Proceedings of the 30th International Conference on Wood Science and Technology - ICWST 2019 "Implementation of wood science in woodworking sector" \& 
70th Anniversary of Drvna industrija Journal (pp. 18-24).

Antov, P., Savov, V., \& Neykov N. (2019). Possibilities for manufacturing insulation boards with participation of recycled lignocellulosic fibres. Journal Management and Sustainable Development (in press).

Antov, P., Savov, V., \& Neykov, N. (2017). Utilization of agricultural waste and wood industry residues in the production of natural fiber-reinforced composite materials. International Journal Wood, Design \& Technology, 6(1), 64-71.

Bouyssou, D. (1999). Using DEA as a tool for MCDM: some remarks. Journal of the Operational, Research Society, 50, 974-978.

https://doi.org/10.1057/palgrave.jors.2600800

Carvalho Araújo, C. K., Salvador, R., Moro Piekarski, C., Sokulski, C. C., de Francisco, A. C., \& de Carvalho Araújo Camargo, S. K. (2019). Circular economy practices on wood panels: a bibliographic analysis. Sustainability, 11(4). https://doi.org/10.3390/su11041057

Charnes, A., Cooper, W., \& Rhodes, E. (1978). Measuring the efficiency of decision making units. European Journal of Operations Research, 2, 429-444. https://doi.org/10.1016/0377-2217(78)90138-8

Coelli, T., Rao, D. S. P., O’Donnell, C. J., \& Battese, G. E. (2005). An introduction to efficiency and productivity analysis. Springer Science-iBusiness Media, Inc.

Cooper, W. W., Seiford, L. M., \& Tone, K. (2007). Data envelopment analysis: a comprehensive text with models. Applications, references, and DEAsolver software (2nd ed.). Springer Science+Business Media.

Daian, G., \& Ozarska, B. (2009). Woodwaste management practices and strategies to increase sustainability standards in the Australian wooden furniture manufacturing sector. Journal of Cleaner Production, 17(17), 1594-1602. https://doi.org/10.1016/j.jclepro.2009.07.008

Diaz-Balteiro, L., \& Romero, C. (2008). Making forestry decisions with multiple criteria: A review and an assessment. Forest Ecology and Management, 255, 3222-3241. https://doi.org/10.1016/j.foreco.2008.01.038

Ellen McArthur Foundation. (2013). Toward circular economy, opportunities for the consumer goods sector.

https://www.ellenmacarthurfoundation.org/assets/d ownloads/publications/TCE_Report-2013.pdf

European Environment Agency. (2016). Circular economy in Europe: Developing the knowledge base (EEA Report No. 2).

https://www.eea.europa.eu/publications/circulareconomy-in-europe

Faraca, G., Tonini, D., \& Astrup, T. F. (2019). Dynamic accounting of greenhouse gas emissions from cas- cading utilisation of wood waste. Science of Total Environment, 651, 2689-2700.

https://doi.org/10.1016/j.scitotenv.2018.10.136

Flandez, J., González, I., El Mansouri, N. E., Vilaseca, F., \& Mutjé, P. (2012). Management of corn stalk waste as reinforcement for polypropylene injection moulded composites. BioResources, 7(2), 1836-1849.

https://doi.org/10.15376/biores.7.2.1836-1849

Forestry Production and Trade. (2020, January 10). http://www.fao.org/faostat/en/\#data/FO

Geldermann, J., Kolbe, L. M., Krause, A., Mai, C., Militz, H., Osburg, V.-S., Schöbel, A., Schumann, M., Toporowski, W., \& Westphal, S. (2016). Improved resource efficiency and cascading utilisation of renewable materials. Journal of Cleaner Production, 110, 1-8. https://doi.org/10.1016/j.jclepro.2015.09.092

Gregson, N., Crang, M., Fuller, S., \& Holmes, H. (2015). Interrogating the circular economy: the moral economy of resource recovery in the EU. Economy and Society, 44(2), 218-243. https://doi.org/10.1080/03085147.2015.1013353

Ionescu, C. A., Coman, M. D., Lixandru, M., \& Groza, D. (2017). Business model in circular economy. Valahian Journal of Economic Studies, 8(4), 101108.

Jawahir, I. S., \& Bradley, R. (2016). Technological elements of circular economy and the principles of 6R-based closed-loop material flow in sustainable manufacturing. Procedia CIRP, 40, 103-108. https://doi.org/10.1016/j.procir.2016.01.067

Jones, J. C., \& Puignou, A. (1998) On the thermal ignition of wood waste. Transactions of the Institution of Chemical Engineers, 76(Part B), 205-210. https://doi.org/10.1205/095758298529498

Kharazipour, A., \& Kües, U. (2007). Wood production, wood technology, and biotechnological impacts: recycling of wood composites and solid wood products (pp. 511-524). Universitätsverlag.

Kies, U., Angerbauer, C., Oberwimmer, R., \& Loyko, L. (2016, May 30). Handbook for resource and energy efficiency in forest-based industries of Eastern Europe.

https://www.researchgate.net/publication/313479060 _Handbook_for_Resource_and_Energy_Efficiency_i n_Forest-based_Industries_of_Eastern_Europe

Knauf, M. (2015). Waste hierarchy revisited - an evaluation of waste wood recycling in the context of EU energy policy and the European market. Forest Policy and Economics, 54, 58-60. https://doi.org/10.1016/j.forpol.2014.12.003

Korkmaz, E. (2011). Measuring the productive efficiency of forest enterprises in Mediterranean Region of Turkey using data envelopment analysis. African Journal of Agricultural Research, 6(19), 45224532. 
Kovalčík, M. (2011). Profitability and competitiveness of Forestry in European countries. Journal of Forest Science, 57(9), 369-376. https://doi.org/10.17221/138/2010-JFS

Largay, J. A. (2005). Standard costing systems. In L. R. Weil, \& Maher, M. (Eds.), Handbook of cost management (pp. 425-464). John Wiley \& Sons, Inc., Hoboken.

Lyubov, V. K., \& Popov, A. N. (2017). Plywood production wastes to energy. Journal of Physics: Conference Series, 891, 012219. https://doi.org/10.1088/1742-6596/891/1/012219

Mair, C., \& Stern, T. (2017). Cascading utilization of wood: a matter of circular economy? Current Forestry Reports, 3, 281-295. https://doi.org/10.1007/s40725-017-0067-y

Mantanis, G., Athanassiadou, E., Coutinho, J. M. A., \& Nakos, P. (2002). A new recycling process for waste panels, in: Management of recovered wood recycling, bioenergy and other options (pp. 204210). Gallis C. (Ur.).

Mantanis, G., Athanassiadou, E., Nakos, P., \& Coutinho, A. (2004, April 5-8). A new process for recycling waste fiberboards. In Proceedings of the 38th International Wood Composites Symposium (pp. 119-122), Washington State University, Pullman, Washington, USA.

McCormick, K., \& Kautto, N. (2013) The bioeconomy in Europe: an overview. Sustainability, 5(6), 25892608. https://doi.org/10.3390/su5062589

Mendes, L. M., Mendes, R. F., Tonoli, G. H., Bufalino, L., Mori, F. A., \& Guimarães Júnior, J. B. (2012). Lignocellulosic composites made from agricultural and forestry wastes in Brazil. Key Engineering Materials, 517, 556-563.

https://doi.org/10.4028/www.scientific.net/KEM.5 17.556

Mihailova, J., Savov, V., \& Grigorov, R. (2019). Utilization of mass of industrial hemp in the production of Medium-density Fibreboards (MDF). Journal of Anatolian Environmental and Animal Sciences, 4(4), 679-683. https://doi.org/10.35229/jaes.637270

Mishra, S., \& Naik, J. (2005). Mechanical properties of wood polymer composites prepared from agrowaste and HDPE. Polymer-Plastics Technology and Engineering, 44, 511-522. https://doi.org/10.1081/PTE-200048310

Odlare, M., Arthurson, V., Pell, M., Svensson, K., Nehrenheim, E., \& Abubaker, J. (2011). Land application of organic waste - effects on the soil ecosystem. Applied Energy, 88, 2210-2218. https://doi.org/10.1016/j.apenergy.2010.12.043

Owoyemi, J. M., H. O., Zakariya, \& Elegbede, I. O. (2016). Sustainable wood waste management in Nigeria. Environmental \& Socio-economic Studies, 4(3), 1-9.

https://doi.org/10.1515/environ-2016-0012
Roundwood removals by type of wood and assortment. (2020, January 9).

https://appsso.eurostat.ec.europa.eu/nui/show.do?d ataset=for_remov\&lang=en

Sawnwood and panels. (2020, January 5). https://appsso.eurostat.ec.europa.eu/nui/show.do?d ataset=for_swpan\&lang=en

Prithivirajan, R., Jayabal, S., \& Bharathiraja, G. (2015). Bio-based composites from waste agricultural residues: mechanical and morphological properties. Cellulose Chemistry and Technology, 49, 65-68.

Roffael, E., Behn, C., Schneider, T., \& Krug, D. (2016). Bonding of recycled fibres with ureaformaldehyde resins. International Wood Products Journal, 7(1), 36-45. https://doi.org/10.1080/20426445.2015.1131918

Risse, M., Weber-Blaschke, G., \& Klaus, R. (2017). Resource efficiency of multifunctional wood cascade chains using LCA and exergy analysis, exemplified by a case study for Germany. Resources, Conservation and Recycling, 126, 141-152. https://doi.org/10.1016/j.resconrec.2017.07.045

Roffael, E., Dix, B., Behn, C., \& Bär, G. (2010). Use of UF-bonded recycling particle and fiber boards in MDF production. European Journal of Wood and Wood Products, 68 (2), 121-128. https://doi.org/10.1007/s00107-009-0376-3

Roffael, E., Athanassiadou, E., \& Mantanis, G. (2002). Recycling of particle- and fiberboards using the extruder technique. In Proceedings of the 2nd Conference on Environ-mental Protection in the Wood Industry (Umweltschutzin der Holzwerkstoffindustrie) (pp. 56-65).

Sikkema, R., Dallemand, J. F., Matos, C. T., van der Velde, M., \& San-Miguel-Ayanz, J. (2017). How can the ambitious goals for the EU's future bioeconomy be supported by sustainable and efficient wood sourcing practices? Scandinavian Journal of Forest Research, 32(7), 551-558. https://doi.org/10.1080/02827581.2016.1240228

Sirkin, T., \& ten Houten, M. (1994). The cascade chain: A theory and tool for achieving resource sustainability with applications for product design. Resources, Conservation and Recycling, 10(3), 213-276. https://doi.org/10.1016/0921-3449(94)90016-7

Sporcic, M., Martinic, I., Landekic, M., \& Lovric, M. (2009). Measuring efficiency of organizational units in forestry by nonparametric model. Croatian Journal of Engineering, 30(1), 1-13.

Stahel, W. (2019). The circular economy: a user's guide. Routledge. https://doi.org/10.4324/9780429259203

Sumardi, I., Dungani, R., Suhaya, Y., Rumidatul, A., \& Rofii, M. N. (2018). Strand boards materials. Alternative materials for strandboards made with waste veneer from industrial plywood. Indonesia BioResources, 13(4), 8385-8393. https://doi.org/10.15376/biores.13.4.8385-8393 
Suttie, E. (2004, March). Wood waste management UK update. In Final Workshop COST Action E22 'Environmental Optimisation of Wood Protection' (22nd-23rd ed.), Lisboa - Portugal.

https://www.researchgate.net/publication/2283878

75_Wood_waste_management_UK_update

Tukker, A. (2015). Product services for a resourceefficient and circular economy - a review. Journal of Cleaner Production, 97, 76-91.

https://doi.org/10.1016/j.jclepro.2013.11.049

Valavanidis, A. (2018). Concept and Practice of the Circular Economy. Turning goods at the end of their service life into resources, closing loops in industrial ecosystems and minimizing waste. http://chem-tox-ecotox.org/wpcontent/uploads/2018/07/CIRCULARECONOMY-REVIEW-JULY2018.pdf
Vis, M., Mantau, U., \& Allen, B. (2016). Study on the optimized cascading use of wood (Final report No. 394/PP/ENT/RCH/14?7689). Brussels.

file://C:/Users/user/Desktop/LTU/Conference/Vil nius-2020/References/Cascade\%20study\%20Executive\%20Summary\%20EN\%202\%20June.pdf

Wan, H., Wang, X.-M., Barry, A., \& Shen, J. (2014), Recycling wood composite panels. BioResources, 9(4), 7554-7565. https://doi.org/10.15376/biores.9.4.7554-7565

Wróblewska, H., Kozik, E., \& Czajka, M. (2008). Effect of compost from wood waste material on the growth and nutritional status of willow Salix alba L. Journal of Research and Applications in Agricultural Engineering, 53(4), 143-147. 